\section{Response to: 'Correspondence on 'Rituximab as therapy to induce remission after relapse in ANCA-associated vasculitis" by Parikh et al}

We appreciate the thorough and thoughtful review of our work, and the interesting points raised by Drs Parikh, Kumar and Rjasekhar. ${ }^{1}$

We recognise that there were more serious and non-serious infections in the lower dose glucocorticoid group in the induction phase of the RITAZAREM trial, which contrasts with the results of the PEXIVAS trial, where serious infections were less frequent in the reduced dose glucocorticoid group. ${ }^{23}$ However, in the RITAZAREM trial, the glucocorticoid induction regimen was not randomised. Reflecting the divergence of opinion on glucocorticoid dosing for disease relapse, the protocol permitted investigators to select, at enrolment, either a higher dose (starting at prednisone/ prednisolone $1 \mathrm{mg} / \mathrm{kg} / \mathrm{day}$, maximum $60 \mathrm{mg}$ ) or a lower dose (starting at $0.5 \mathrm{mg} / \mathrm{kg} / \mathrm{day}$, maximum dose $30 \mathrm{mg}$ ) glucocorticoid induction regimen. Therefore, the selection of glucocorticoid dose is susceptible to bias. Trial participants with a perceived greater risk of infection (such as those with preexisting comorbidities, older age, or greater prior burden of immunosuppression) may have been enrolled into the lower dose group. Per our prespecified statistical analysis plan, we reported the data but did not perform formal statistical analysis since the study was not powered to detect a difference between high-dose and low-dose glucocorticoids on rates of infection. Further analyses on the effects of glucocorticoid dose on both efficacy and safety parameters across all phases of the trial are planned.

Serious adverse events which could be attributed to active disease were observed. However, induction of remission is not an immediate event, and, therefore, it is not unexpected that some patients were readmitted to hospital during the first few weeks of treatment. By 4 months, $90 \%$ of patients met the remission definition for this trial (BVAS/WG $\leq 1$, and prednisone/prednisolone dose $\leq 10 \mathrm{mg}$ daily). Venous thromboembolic events occur in $>10 \%$ of patients with antineutrophil cytoplasmic autoantibody (ANCA)-associated vasculitis with active disease. ${ }^{45}$ It is likely that these events reflect active disease, but are not recorded on the BVAS/WG disease assessment tool. In addition, it is particularly difficult to evaluate some clinical features such as laryngeal stenosis, and to distinguish active disease from damage. These points highlight the limitations of current disease activity assessment tools in ANCA-associated vasculitis and the challenges of defining disease remission.

\section{Rona M Smith $\odot,^{1,2}$ Peter A Merkel, ${ }^{3}$ David Jayne ${ }^{1,2}$ \\ ${ }^{1}$ Department of Nephrology, Cambridge University Hospitals NHS Foundation Trust, Cambridge, UK \\ 2Department of Nephrology, University of Cambridge, Cambridge, UK \\ ${ }^{3}$ Division of Rheumatology, Department of Medicine and Division of Clinical Epidemiology, Department of Biostatistics, Epidemiology and Informatics, University of Pennsylvania, Philadelphia, Pennsylvania, USA}

Correspondence to Dr Rona M Smith, Department of Nephrology, Cambridge University Hospitals NHS Foundation Trust, Cambridge CB2 1TN, UK; ronasmith@doctors.net.uk

Handling editor Josef S Smolen

Contributors RMS wrote the manuscript with support from DJ and PM.

Funding RITAZAREM is funded by grants from Versus Arthritis (formerly Arthritis Research UK) (Grant number 18706) and Roche/Genentech (MA28150).
The Vasculitis Clinical Research Consortium (VCRC) (U54 AR057319 and U01 AR5187404) is part of the United States National Institutes of Health Rare Diseases Clinical Research Network, an initiative of the Office of Rare Diseases Research, National Center for Advancing Translational Science (NCATS). The VCRC is funded through collaboration between NCATS, and the National Institute of Arthritis and Musculoskeletal and Skin Diseases, and has received funding from the National Center for Research Resources (U54 RR019497). The Research Committee on Intractable Vasculitides, the Ministry of Health, Labour and Welfare of Japan. This research was also supported by the National Institute for Health Research, Cambridge Biomedical Research Centre and the Cambridge Clinical Trials Unit.

Competing interests RMS reports grants from Roche during the conduct of the study. PM reports personal fees from AbbVie, grants and personal fees from AstraZeneca, personal fees from Biogen, grants and personal fees from BristolMyers Squibb, grants and personal fees from Boeringher-Ingelheim, grants and personal fees from Celgene, grants and personal fees from ChemoCentryx, CSL Behring, grants and personal fees from Genentech/Roche, grants and personal fees from Genzyme/Sanofi, grants and personal fees from GlaxoSmithKline, grants and personal fees from InflaRx, personal fees from Insmed, personal fees from Jannsen, personal fees from Kiniksa, grants from Kypha, personal fees from Sparrow, grants from TerumoBCT outside the submitted work. DJ reports grants from Roche/Genentech, during the conduct of the study; grants from SanofiGenzyme, grants and personal fees from Chemocentryx, grants and personal fees from GSK, grants from Roche/Genentech, personal fees from Takeda, personal fees from Insmed, personal fees from Astra-Zeneca, personal fees from Infla-RX, personal fees from Chugai, personal fees from Boehringer-Ingelheim outside the submitted work

Patient and public involvement Patients and/or the public were involved in the design, or conduct, or reporting, or dissemination plans of this research. Refer to the Methods section for further details.

Patient consent for publication Not required.

Ethics approval An initial favourable ethical opinion was granted by NRES Committee East of England - Cambridge South: REC reference: 12/EE/0230 on 24 July 2012. US approvals: Cedars-Sinai Medical Center Institutional Review Board: Pro00031367; Cleveland Clinic Institutional Review Board: 13-666; Hospital for Special Surgery Institutional Review Board: 13114; Mount Sinai Hospital Research Ethics Board: 12-0231-A; St. Joseph's Hospital Hamilton Integrated Research Ethics Board: 13-037; University of Pittsburgh Institutional Review Board: PR013020329; University of Pennsylvania Office of Regulatory Affairs: 816166; The Mayo Clinic, University of Michigan, University of North Carolina and the University of Utah all deferred to the University of Pennsylvania Ethics board and fall under the University of Pennsylvania approval number. Japanese ethics committee numbers: University of Miyazaki 2013-126; Chiba University 97; Kitano Hospital P14-01-002; Okayama University m05002; Kyorin University H26-031; Teikyo University 14-031; TMGH 260201

Data availability statement Data are available on reasonable request. Deidentified participant data can be requested from the corresponding author.

(C) Author(s) (or their employer(s)) 2021. No commercial re-use. See rights and permissions. Published by BMJ.

\section{Check for updates}

To cite Smith RM, Merkel PA, Jayne D. Ann Rheum Dis Epub ahead of print: [please include Day Month Year]. doi:10.1136/annrheumdis-2020-219329

Received 29 October 2020

Accepted 30 October 2020

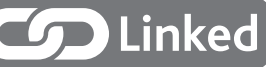

- http://dx.doi.org/10.1136/annrheumdis-2020-219312

Ann Rheum Dis 2021;0:1-2. doi:10.1136/annrheumdis-2020-219329

ORCID iD

Rona M Smith http://orcid.org/0000-0002-7438-5156

\section{REFERENCES}

1 Parikh AKP, Rajasekhar L. Correspondonce on "Rituximab as therapy to induce remission after relapse in ANCA-associated vasculitis". Ann Rheum Dis 2021. doi:10.1136/annrheumdis-2020-219312

2 Smith RM, Jones RB, Specks $\mathrm{U}$, et al. Rituximab as therapy to induce remission after relapse in ANCA-associated vasculitis. Ann Rheum Dis 2020;79:1243-9.

3 Walsh M, Merkel PA, Peh C-A, et al. Plasma exchange and glucocorticoids in severe ANCA-associated vasculitis. N Eng/ J Med 2020;382:622-31. 
4 Merkel PA, Lo GH, Holbrook JT, et al. Brief communication: high incidence of venous thrombotic events among patients with Wegener granulomatosis: the Wegener's clinical occurrence of thrombosis (WeCLOT) study. Ann Intern Med 2005;142:620-6.
5 Kronbichler A, Leierer J, Leierer $\mathrm{G}$, et al. Clinical associations with venous thromboembolism in anti-neutrophil cytoplasm antibody-associated vasculitides. Rheumatology 2017;56:kew465-8. 